\title{
Innovativeness Dimensions and Growth of University Students' Owned Micro Enterprise in Moshi Tanzania: An Empirical Study
}

\author{
Placid Ernest Komba \\ Archbishop Mihayo University College of Tabora (AMUCTA), \\ ernestplacid@yahoo.com \\ Isaac Kazungu \\ Moshi Co-operative University, Moshi, Tanzania, isaackazungu@gmail.com
}

\begin{abstract}
This study assessed the influence of innovativeness dimensions towards the growth of university students owned micro enterprises in Moshi Tanzania. Data were analysed by using descriptive and inferential statistics. Binary regression was used to model the relationship between innovativeness and firm growth. The study found out that the innovation dimensions have a significant positive influence on growth of Micro Enterprises. The findings indicated that innovation (pvalue $=0.001$ ) had an effect on the growth of micro enterprises. The study recommends that micro enterprise owners should encourage innovative tendencies among employees in order to encourage firm growth, competitive, profitability and survival.
\end{abstract}

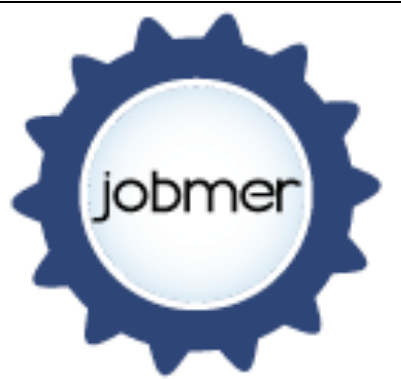

Journal of Business

Management and Economic Research

Vol.2, Issue.7, 2018

pp.1-11

Key Words: Innovativeness, Growth, University Students, Micro

Doi: 10.29226/TR1001.2018.45 Enterprises, and Moshi - Tanzania

\section{Introduction}

Micro enterprises ${ }^{1}$ play a very important role in the economies of developed and developing countries (Lameck, 2014; Karpak and Topcu, 2010). They contribute to even and equitable economic development process (Memba, Gakure and Karanja, 2012). MEs are the engine of global economic development as they constitute over $90 \%$ in the economies. Their contributions to the economic development, income generation and poverty alleviation is widely recognized and known (ILO, 2007; Rao \& Joshi, 2011, Muthee-Mwangi \& Ngugi, 2014). They contribute to

\footnotetext{
${ }^{1}$ In Tanzania, majority of micro enterprises (MEs) fall under the informal sector and engaging up to 4 people, employing capital amounting up to Tshs.5 million (URT, 2012), they contribute about a third of Tanzania's GDP, many are survivalists, few of them grow into medium and large firms, while many others are struggling to grow (Rutashobya, et al., 2015). They are labor-intensive in nature and have been established using savings or grants from family and friends (Madatta, 2011). MEs are easy to establish as they require less in terms of capital, technology, management and even utilities (UK Essay, 2015).
} 
employment creation (Lukes \& Laguna, 2010; Naude, 2013), income, investments, and manufactured exports (Ngugi, 2012), country's Gross Domestic Product (GDP) (Ankunda, 2010; Katua, 2014), training ground for the development of entrepreneurship skills (Kazungu \& Panga, 2015; Kazungu, Ngugi, Rotich and Odhiambo, 2018), government revenue in way of taxation, poverty alleviation and economic development (Okeyo, Gathungu, \& K'Obonyo, 2014), new methods, technology and overall economic growth (Yahya \& Mutarubukwa, 2015).

Micro Enterprises are a key driver of economic and social development in the African context. They are hailed for their pivotal role in promoting grassroots economic growth and equitable sustainable development (Kiraka, Kobia, and Katwalo (2013). Micro enterprises formulate growth strategies for high market share, productivity and profitability (Anyanga and Nyamita, 2016). Growth ${ }^{2}$ of micro enterprises thus contributes to employment and job creation, opportunity for financial gain, return on investment and increased chances for survival (Dobbs and Hamilton, 2007).

Despite their contributions to the national economy, fast changing and intense worldwide competitive environment have placed micro enterprises in a vulnerable position, then to deal with these challenges it is suggested that innovativeness ${ }^{3}$ be put to the forefront and lead to higher performance (Wiklund and Shepherd, 2009). Businesses that act entrepreneurially are able to exploit new market opportunities and are better equipped to respond to the challenges of a competitive and uncertain business environment (Anderson \& Eshima 2013, Liet al., 2009). When a business has a willingness to innovate it is said that the business is entrepreneurially orientated (Franket al., 2010). Many challenges which were thought to be responsible for the incumbent poor performance of micro enterprises in Tanzania, have been widely researched and its recommendations implemented, yet no appealing improvement have been realized. To date 3 out of every 5 micro enterprises established fail within a period of less than five years from their establishment and the surviving firms are usually stagnant (Mgeni, 2016).

In Tanzania a graduate's decision to become self-employed has been a battle with the existing norms that envision graduates as salaried employees. Although the current government strives for graduate entrepreneurship and self-employment, it has not been able to erase the institutional legacy of Ujamaa completely (Mwasalwiba, et al. 2012). Falling rates of graduates' business start-up among graduates in Tanzania, is contributed by two main factors which are factors within the capability and those which are outside the control of capable which all together make a total of $13.3 \%$ despite efforts in teaching entrepreneurship issues in universities (Mwasalwiba et al., 2012). Kubegeya (2010) further argues that the idea of being an employer as one completes college or university education is still alien to the majority of Tanzanian university students.

\footnotetext{
${ }^{2}$ Measured in-terms of financial or employees, numbers increase of sales, return on equity and accumulation of asserts all represent growth (Gatenya, 2012).

3 The degree to which an individual or an entity is relatively earlier in adopting new ideas than the other members of a system, a tendency to support new ideas, experimentation and creative processes of the business organization (Oscar and Hassan, 2013). A specific tool of entrepreneurs' means by which they exploit change as an opportunity for a different business or service (Schillo, 2011).
} 
As stated by ESRF (2014), 36.9\% of MEs in Tanzania passed have succeeded to grow more in higher level and while the remaining $63.1 \%$ fail to grow and reach the upper level of the business such as expanding the business activities and market. This is to say Tanzania is still in its infancy and is facing a number of inhibitors, including the difficulties in raising start-up capital, inhibitive banking and taxation systems, problems of trust, poor technology, negative attitudes, corruption, poor policy implementation at lower levels of government, and the increasing threat from cheap imports from countries like China. Hence micro enterprises need to act entrepreneurially in order to cope with the dynamic environment which requires the business to be innovative to ensure its growth and survival. Therefore this study therefore assessed influence of innovativeness behavior on the growth of university students owned micro enterprise in Moshi Tanzania.

Enterprise Growth strategies are classified by Hyland (2013) as either organic or inorganic clusters. Companies growing organically not only measure their success on financial metrics but also they take note of other internal metrics like customer satisfaction, in-house competencies and product quality. Inorganic (external) strategies deal with increasing output and business reach by acquiring new businesses by way of mergers or acquisitions (Hyland, 2013). The growth of micro enterprises may be measured specifically in-terms of financial or employees, numbers increase of sales, return on equity and accumulation of asserts all represent growth (Gatenya, 2012). In this study both organic or inorganic clusters were used to measure the growth of students owned micro enterprises using increase in sales, number of employees and profitability. In this study, Innovation was meant to be the way in which organization develop new products or services, develop the existing product or services and also new process are being developed in order to gain competitive advantage in the market or to win the market in a competing environment.

\section{Materials and Methods}

The study was conducted in Moshi Municipality using a Cross sectional design. The design fitted well with the nature of the study, as it allowed measurements of the correlations between study variables. Snowball sampling technique and Raosoft sample size calculator were used to identify 117 students involved in the study with the margin of error of $5 \%, 95 \%$ confidence level and 50\% skeweness level. Survey Questionnaire was the main tool when collecting primary data in the field of the study. A total of 117 closed ended survey questionnaires were administered to the respondents from four Universities in Moshi Municipal. Secondary data were obtained from different sources with the use of documentary review. Data were obtained from documents like Tanzania SMEs development policy of 2003, report on Capacity of Tanzanian MSMEs in tapping the business opportunities in the East African Community of 2015 by, report by Organization for Economic Co-operation and Development (OECD) on promoting SMEs for development. Different journal articles on the influence of networking on the growth of MEs were also reviewed.

Qualitative data were analyzed to provide information which show socio-demographic characteristics of the respondents like marital status, age of the respondents' experience of the respondent, type of enterprise owned, years spent in operation, then data were interpreted using descriptive statistics where frequencies and percentage were used in interpretation of the data analyzed. Quantitative data were analyzed by using descriptive statistics (frequencies and percentage) and binary logistic regression analysis. The model was applied because it makes use of several independent variables as well as categorical dependent variables, and hence the study used the following binary logistic regression model: 


\section{Econometric Model}

$$
\operatorname{Logit}[p(x)]=\log \left[\frac{p(x)}{1-p(x)}\right]=\alpha+\beta_{1} x_{1}+\beta_{2} x_{2}+\beta_{3} x_{3}+\cdots \ldots+\text { Equation (1). }
$$

Logistic regression involves fitting an equation of the following form of data:

$$
\operatorname{Logit}\left(p_{1}\right)=\alpha+\beta_{1} x_{1}+\beta_{2} x_{2}+\beta_{3} x_{3}+\cdots \ldots \ldots \ldots \beta_{p} x_{p, i}+\cdots \ldots \ldots+\text { Equation (2). }
$$

Where:

Logit $\left(p_{i}\right)=Y$; is binary and represents the probability of MEs growth or not growth of MEs, coded as $0 / 1$ respectively.

$\beta_{1}-\beta_{\mathrm{p}}=$ Regression coefficients

$\alpha=$ Intercept

$\mathrm{X}_{1,1}-\mathrm{X}_{\mathrm{p}, 1}=$ Independent variables or predictor variables

$\mathrm{e}_{\mathrm{o}}=$ Error term

To ensure validity before the actual data collection, a pilot study was carried out to check the accuracy of instruments in order to make corrections where necessary. In this study 14 questionnaires were administered to test the reliability and validity of the questionnaires. The proposed pilot test falls within the rule of thumb by Cooper et al (2012), Cooper and Schilder (2011) and Creswell (2009) that 1\% of the sample should constitute the pilot test. A pilot study was also conducted to test the reliability and validity of the study and hence to detect errors in the data collection process. This helped to discover errors on the issues raised such as ambiguous instruction or wording, inadequate time and measurability of variables defined. To test the reliability, Cronbach Alpha was conducted. It can be seen that responses from data gathered were reliable since all the Cronbach Alpha scores for the variable were above the accepted 0.6 marks of which was 0.842 .

\section{Findings and Discussions}

\section{Socio-Demographic Characteristics of Respondents}

In order to assess the influence of innovativeness to the growth of university students owned Micro Enterprises, it was necessary to know the gender of the respondents as one of the attribute in socio-demographic characteristics of the sample. Findings in table 1 showed that males involve more in establishing micro enterprises than female, whereby male are of $53.8 \%$ and females were $46.2 \%$ of the sample population. However findings show that all types of gender participate in establishing micro enterprises, the magnitude difference between male and female was almost $7.6 \%$ which was not much significant. The findings were supported by study done by study Rosli and Sidek (2013) who observed more of male domination in a study on the impact of innovation on the performance of small and medium manufacturing enterprise. Tifre (2014) was consistence with findings of the study who got many male than female in such that out of the 333 respondents, 259 SEs $(77.78 \%)$ are male owned which registered higher growth rate than those female owned small enterprises (7.25 percent against 6.52 percent for female). The findings showed that growth rate of female owned SEs is $1.15 \%$ lesser than those male owned ones, though it is statistically insignificant.

As for age of MEs owners, results in table 1 shows that greater percentage of age group is below 30 years which is $49.6 \%$, followed by $30-40$ years which is $26.5 \%, 40-50$ and above 50 years were $16.2 \%$ and $7.7 \%$ respectively. This implied that most university students are youths, they are able and capable to maintain the operations of micro enterprises. The findings of the study are 
relevant to those of Alembummah (2015) where respect to age, $29 \%$ of respondents fall within the ages of $25-34$. The rest were within the ages of 45-54, 35-44, 56-65 and 18-24 representing $28 \% \mathrm{t}, 22 \%, 14 \%$ and $7 \%$ respectively. The findings are against Kamendi (2016) who focused on the role of entrepreneurial orientation on the growth of small and medium enterprises in Nairobi, the findings showed that shows that majority (48\%) of the respondents was in the age category of $30-40$ years, $24 \%$ were in the age category of $20-30$ years, $21 \%$ were in the age category of $40-50$ years and $7 \%$ were above 50 years.

Table 1 shows that majority of respondents were pursuing bachelor degrees (57.3\%) followed by diploma level $(17.9 \%)$, masters level $(16.2 \%)$ and certificate level $(8.5 \%)$. Results imply that bachelor degree shows more response in establishing micro enterprises. The findings related to the study done by Kamendi (2016) where majority (45\%) of the respondents had university qualification followed by $37 \%$ who had Certificate/ Diploma and 18\% Secondary School certificates. Joppe (2000) did a similar study and found out that respondents which high education level have technical knowledge on the study problem assists in gathering reliable and accurate data on the problem under investigation. This demonstrated that most of the micro enterprises owners possessed qualified professional skills and technical knowledge on study and thus provided the study with reliable information on innovativeness dimensions and growth of small and medium enterprises.

Table 1: Gender Distribution of the Respondents

\begin{tabular}{llcc}
\hline Socio-Demographic factor & Category & Frequency $\mathbf{( n = 1 1 7 )}$ & Percent (\%) \\
\hline \multirow{2}{*}{ Gender } & Male & 63 & 53.8 \\
& Female & 54 & 46.2 \\
\hline \multirow{3}{*}{ Age bracket } & Below 30 years & 58 & 49.6 \\
& $30-40$ years & 31 & 26.5 \\
& $40-50$ years & 19 & 16.2 \\
& Above 50 years & 9 & 7.7 \\
\hline \multirow{3}{*}{ Educational Level } & Certificate & 10 & 8.5 \\
& Diploma & 21 & 17.9 \\
& Bachelor degree & 67 & 57.3 \\
& Masters & 19 & 16.2 \\
\hline
\end{tabular}

\section{Business Characteristics}

From the field of the study, the number of employees determines the size of the business entity, hence it was important to know the number of employees in order to know the size of business operation. However the number of employees from the business organization usually differs from one entity to another entity with regards to the size of organization, the table below shows results from the field of the study. Findings in table 2 showed that there is a great number of micro business organizations which have employed number of people ranging from 1-4 employees which accounted for about $74.4 \%$ out of the total population from the field of the study, but also other Es with 5-10 employees not only that but also the researcher observed other organization having more than 10 employees which accounted for $22.2 \%$ and $3.4 \%$ respectively.

Years of operation of business organization basically means the existence of business organization since it has been established. Results in table 2 shows that $63.2 \%$ were established between zero and 5 years of operation, $34.2 \%$ between $5-10$ years and $2.6 \%$ for a period of $11-15$ 
years. This implied that more of students who own the micro enterprises have not been established for a long period of time and this is because motivational given in schools and other motivators such carrier days pushes them into establishing and operating micro enterprises. Findings of the current study differs from those of Kamendi (2016) where majority (43\%) has been in operation for a period of 6-10 years, $26 \%$ for a period of $11-15$ years, $24 \%$ for a period of less than 5 years and $7 \%$ for 15 years and above.

Results in table 2 show revenues were grouped into groups where respondents were required to choose among the group of revenue that his/her organization fits on and the results were as follows 1-2.5 million, 2.5-3.5 million, above 5 million, 3.5-5 million and last was below 1 million were $32 \%, 30 \%, 22 \%, 19$ and $14 \%$ respectively, the table below shows the distributions of results as obtained from the field of the study. This implies that there was quite different revenue earned with different Es. That is to say periodic (yearly) revenue differ with the nature and type of business that is being established and operated, not only that but also it shows that the nature of customers that a business is serving.

Table 2: Business Characteristics

\begin{tabular}{llcc}
\hline Business characteristic & \multicolumn{1}{c}{ Category } & Frequency (n=117) & Percent (\%) \\
\hline \multirow{3}{*}{ Number of employees } & 1-4 employees & 87 & 74.4 \\
& 5-10 employees & 26 & 22.2 \\
& 11-15 employees & 4 & 3.4 \\
\hline \multirow{3}{*}{ Years of Operation } & Below 5 years & 74 & 63.2 \\
& 5-10 years & 40 & 34.2 \\
& 11-15 years & 3 & 2.6 \\
\hline \multirow{5}{*}{ Turnover per Year } & Below 1 million & 14 & 12.0 \\
& 1-2.5 million & 32 & 27.4 \\
& 2.5-3.5 million & 30 & 25.6 \\
& 3.5-5 million & 19 & 16.2 \\
& Above 5 million & 22 & 18.8 \\
\hline
\end{tabular}

\section{Correlation between Variables}

To understand the relationship between Innovativeness and Micro enterprises growth, Pearson Correlation Matrix was done. This type of test gives evidences as to existence of the relation between the dependent and independent variables. It also indicates the state of inter-correlation between the independent variables. Table 3 shows findings of the correlation between variable construct.

Table 3: Correlation between Variables.

\begin{tabular}{llcc}
\hline Variables & & Innovation & MEG \\
\hline \multirow{3}{*}{ Innovation } & Pearson & 1 & \\
& $\begin{array}{l}\text { Correlation } \\
\text { Sig. (2-tailed) }\end{array}$ & & \\
Pearson & $.237^{*}$ & 1 \\
CEG & Correlation & & \\
& Sig. (2-tailed) & .010 & \\
\hline
\end{tabular}

\section{Innovativeness and Growth of Micro Enterprises}

In order to assess the influence of innovation on growth of micro enterprises, it was important to know as to whether micro enterprises introduce new services/products/process regularly or 
not. Results show that $77.8 \%$ of the respondents agree that their business introduce new products. $88.1 \%$ agreed that their business places a strong emphasis on new and innovative products/services. Results further shows that $89.8 \%$ of respondents agreed to pursue new opportunities, $59.8 \%$ agreed that over the past few years, changes in their processes, services and product lines have been quite dramatic. $78.9 \%$ agreed that their business have demonstrated a strong relationship between the number of new ideas generated and the number of new ideas successfully implemented. $85.4 \%$ of business places a strong emphasis on continuous improvement in products/service delivery, and $91.4 \%$ agreed that their businesses have a widely held belief that innovation is an absolute necessity for the business" future.

As in Namusonge and Martin (2014) findings of this study proves that innovation is such a vital component in business undertakings, and that without it, it is virtually impossible for a business to survive due to the increased competition that is observed within industries. Therefore for a business to thrive and grow, owner-managers must see innovation as a proponent of business success. Findings further agrees with Ailian (2010) who raised that enterprises with strong absorption ability could obtain innovative information provided by suppliers in open innovation which can enhance innovative performance, however, poor absorption capacity of SME opening to suppliers may reduce innovation performance taking 109 small and medium electronic technology enterprises as objects.

Table 5: Innovativeness Behavior and Growth of University Students Owned Micro Enterprises

\begin{tabular}{|c|c|c|c|c|c|}
\hline Measures & SA & A & $\mathbf{N}$ & $\mathbf{D}$ & SD \\
\hline $\begin{array}{l}\text { Our } \quad \text { business } \\
\text { services/products/processes }\end{array}$ & 29.1 & 48.7 & 21.4 & 0.9 & 00 \\
\hline $\begin{array}{l}\text { Our business places a strong emphasis on new and innovative } \\
\text { products/services }\end{array}$ & 38.5 & 49.6 & 11.1 & 0.9 & 00 \\
\hline Our business is continually pursuing new opportunities. & 34.2 & 55.6 & 10.3 & 00 & 00 \\
\hline $\begin{array}{l}\text { Over the past few years, changes in our processes, services and } \\
\text { product lines have been quite dramatic }\end{array}$ & 5.1 & 54.7 & 18.8 & 17.1 & 4.3 \\
\hline $\begin{array}{l}\text { In our business there is a strong relationship between the } \\
\text { number of new ideas generated and the number of new ideas } \\
\text { successfully implemented }\end{array}$ & 18.8 & 59.8 & 19.7 & 1.7 & 00 \\
\hline $\begin{array}{l}\text { Our business places a strong emphasis on continuous } \\
\text { improvement in products/service delivery }\end{array}$ & 50.4 & 35 & 14.5 & 00 & 00 \\
\hline $\begin{array}{l}\text { Our business has a widely held belief that innovation is an } \\
\text { absolute necessity for the business" future }\end{array}$ & 48.7 & 42.7 & 6.8 & 00 & 1.7 \\
\hline
\end{tabular}

$\mathrm{SD}=$ Strongly Disagree, $\mathrm{D}=$ Disagree, $\mathrm{N}=$ Neutral , $\mathrm{A}=$ Agree, $\mathrm{SA}=$ Strongly Agree

Results of hypothesis testing

As seen in Table 6, the model produced positive and significant relationship innovativeness and the growth of university students owned micro enterprise in Tanzania $(\beta=3.305$, and $p=0.001)$. Therefore, $\mathrm{H}_{\mathrm{A}}$ is confirmed, which means that there was a positive significant relationship between innovativeness behaviour and the growth of university students owned micro enterprise in Tanzania. This implies that micro enterprises owned by university students are innovative for their survival in the market operation. These findings corroborate those by Kumarpeli and Semasinghe (2015), who confirmed that willingness to engage in relatively high levels of risk-taking behaviors helps a firm seize profitable opportunities in the face of uncertainty and the achievement of long-term profitability. But also another supportive study done the results were, however, in contrast with Bruderl and Preisendorfer (2000) who stated 
that in predicting firm growth, one important factor that cannot be overlooked is innovation. Boohene, Marfo-yiadom and Yeboah's (2012) were with the same results who found that a positive and significant relationship between innovativeness and growth of businesses.

Table 6: Relationship between Innovation and Growth of USoMEs

\begin{tabular}{llllllllr}
\hline & \multirow{2}{*}{$\boldsymbol{\beta}$} & S.E. & \multirow{2}{*}{ Wald } & df & Sig. & Exp (B) & \multicolumn{2}{c}{ 95\% C.I.for EXP(B) } \\
& & & & & & & \multicolumn{1}{c}{ Lower } & Upper \\
\hline Innovation & 3.054 & .936 & 10.646 & 1 & .001 & 21.200 & 3.385 & 132.759 \\
Constant & .511 & .730 & .489 & 1 & .484 & 1.667 & & \\
\hline
\end{tabular}

Variable(s) Innovation.

\section{Conclusions and Recommendations}

The findings showed that innovation contributes largely to the growth of university students owned micro enterprise. This has evidenced by findings from descriptive statistics where findings showed that $81 \%$ out of the total population agreed on as innovation is the key contribution dimension of EO towards growth of micro enterprise, though $15 \%$ out of population were neutral and $4 \%$ out of the total population disagree. Not only that but also the binary logistic regression showed that emphasis on new innovative products which had a Pvalue of 0.008 with coefficient of $\beta=1.854$ indicating that most of the micro enterprise university students owned by university students are innovative in nature and therefore they are able to maintain the competition in the market.

This study therefore recommends Micro Enterprises owners to encourage the innovativeness behaviour to among the employees and explore their creativity and welcoming new ideas from different stakeholders without regarding their status in the business organization, flexibility and creating an enabling, relaxing and flexible working environment devoid of stringent structures to allow the free flow of work and assigned tasks. Also the owners/students of micro enterprises should introduce new products/services for the purpose of capturing the tension of the market and also challenge the competitors with regards to market operation. The study covered only small geographical area especially in Moshi in Tanzania, but still there are other regions and countries where entrepreneurial activities are being practiced, hence for the sake of transferring knowledge, it is recommended that other studies can be carried out in Tanzania and other East African countries.

\section{References}

Ailian, Y. (2010). Entrepreneurial Orientation and Business Performance of Small and Medium Scale Enterprise of Hambantota District of Sri Lanka, Journal of Asian Social Science. 6(3): 34-56.

Alembummah, A. B. (2015). Entrepreneurial orientation and small business growth, A study of the food processing sector of Ghana.

Anderson, B. S., and Eshima, Y. (2013). The influence of firm age and intangible resources on the relationship between entrepreneurial orientation and firm growth among Japanese SMEs, Journal of Business Venturing. 28(13): 413-429. 
Anyanga, S. O. and Nyamita, M. O. (2016). The Major Growth Strategies Adopted by Small and Medium Enterprises in Kenya: A Case of Kisumu County, International Journal of Advanced and Multidisciplinary Social Science, 2(1): 11-26.

Boohene, R., Marfo-Yiadom, E., and Yeboah, M.A. (2012). An empirical analysis of the effect of entrepreneurial orientation on firm performance of auto artisans in the Cape Coast Metropolis. Developing County Studies. 2(9): 77- 88.

Bruderl, J. and Preisendorfer, P. (2000). Fast growing business. Empirical evidence from a Germany study. International journal of sociology. 30: 45-70.

Callaghan, P. (2009). Introduction: Mental nursing past, present, and future. Callaghan, J. Playle and L. Cooper (eds) Mental Health Nursing Skills. Oxford: Oxford University Press.

Cooper, A. C. and Gascon, F. D. Sexton and Kasarda, J. (2012). Entrepreneurs, processes of founding and new-firm performance in the state of the art of entrepreneurship, (eds.) PWS-Kent, Boston.

Cooper, D., and Schinlder, P. (2011). Business research method. New York : McGrow-Hill Higher Education.

Creswell, J. W. (2009). Research Design: Qualitative, Quantitative, and Mixed Methods Approaches. 3rd Edition. Los Angeles: Sage Publications, Inc.

Dobbs, H., and Hamilton, J. (2007). Angels on Angels Financing Technology based Ventures. A Historical perspective of Venture Capital. Journal of Entrepreneurial Finance. 4(4): 275287.

Evans, D. S. (1987). The relationship between firm growth, size, and age estimates for 100 manufacturing industries, in. Journal of Industrial Economics. 35 (4): 567-581.

Frank, H., Kessler, A., and Fink, M. (2010). Entrepreneurial orientation and Business Performance.

Hyland, B. (2013). Growth strategies for SMEs. Business international. 2(11): 34-44.

ILO, (2007). The report on the ILO Conclusions concerning the promotion of sustainable enterprises International Labor Conference, ILO: Geneva.

ILO, (2015). The report on the ILO on world employment and social outlook, the changing nature of jobs, ILO: Geneva.

Inyang, B. J., and Enouh, R. O. (2009). Entrepreneurial Competencies: The Missing Links to Successful Entrepreneurship in Nigeria. International Business Research.2(2): 62-71.

Joppe, M. (2000). The Research Process. Retrieved April 16, 2017, from http://www.ryerson.ca/ mjoppe/rp.htm.

Kamendi, B, (2016). The Role of entrepreneurial orientation on the growth of small and medium enterprises in Nairobi County.

Karanja, J. N., Mwangi, E. and Nyanga, P. (2013). Adoption of modern management accounting technique in SMEs in developing countries: A case study of SMEs in Kenya.

Karpak, B., and Topcu, I. (2010). Small medium manufacturing enterprises in Turkey: an analytic network process framework for prioritizing factors affecting success. International Journal of Production Economics. 125(1):60-70. 
Kiraka, R., Kobia, M. and Katwalo, A. (2013). Micro, Small and Medium Enterprises Growth and Innovation in Kenya. A case study on the Women Enterprise Fund. Investment Climate and Business Environment Research Fund.

Kubegeya, M. (2010). Tanzania: Catching graduates young to run their own business.

Lin, Y., and Chen, M. (2017). Does Innovation Lead to Performance? An Empirical Study of SMEs in Taiwan. Management Research News. 30(2): 115-132.

Lukes, M. and Laguna, M. (eds.) (2010). Entrepreneurship: A psychological approach. Prague.

Madatta, (2011). Entrepreneurial Orientation and Business Performance of Small and Medium Scale Enterprises of Hambantota District Sri Lanka.

Madhoushi, M., Sadati, A., Delavari, H., Mehdivand, M., and Mihandost, R. (2011). Entrepreneurial Orientation and Innovation Performance. The Mediating Role of Knowledge Management, Asian Journal of Business Management. 3(4): 310-316.

Matchaba, J., and Vombe, G. (2014). Entrepreneurial Orientation and Firm Performance: A Critical Examination. Journal of Business and Management. 18(4): 21-28.

McClelland, D. C. (1961). Methods of measuring human motivation. In J. W. Atkinson (Ed.). Motives in fantasy, action, and society.7-42.

Memba, S. F., Gakure W. R., and Karanja, K. (2012). It's Impact on Growth of Small and Medium Enterprises in Kenya. International Journal of Business and Social Science. 3(6): 3241.

Mgeni, T.O. (2016). Impact of Transformational Leadership Style on Business Performance of Small and Medium Enterprises in Tanzania. The international journal of business and management. 4(2): 2321-8916.

Mwangi, M. M., A and Ngugi, K.(2014). Influence of Entrepreneurial Orientation on Growth of Micro and Small Enterprises in Kerugoya, Kenya. European Journal of Business Management. 1(11): 417-438.

Mwangi,S., Martin and Namusonge M.J. (2014). Influence of Innovation on Small and Medium enterprises (SMEs) Growth. International Journal for Innovation education and Research. 2(6): 102-112.

Namusonge, M. J. (2014). Linking competencies with strategies: The case of small and mediumsized exporting firms in Kenya. International Journal of Social Sciences and Entrepreneurship.1 (11):418-439.

Ngugi, J. K., McOrege, M.O., and Muiru, J.M. (2013). The Influence of Innovativeness on the Growth of SMEs in Kenya. International Journal of Business and Social Research. 3 (1): 2531.

OECD, (2014). Promoting Entrepreneurship and innovative SMES in a global Economy: Towards a more responsible and inclusive globalization, Instabul, Turkey.

OECD. (2011). Small Businesses, Job Creation and Growth: Facts, Obstacles and Best Practices. Paris, France.

Peljhan, D., and Tekavcic, M. (2012). Effects of Strategic Change from Defender to Prospector on the Use of Management Control Systems. World Journal of Social Sciences. 2(1): $45-53$. 
Rao, V., and Joshi, H.G. (2011). Entrepreneurship Training in Apparel and Fashion Design Sector through Distance Mode: A strategy for facing the Challenge of growing Unemployment in India.

Rosli, M. M., and Sidek, S. (2013). The Impact of Innovation on the Performance of Small and Medium Manufacturing Enterprises: Evidence from Malaysia. Journal of Innovation Management in Small and Medium Enterprise. 4(4): 82-92.

Rutashobya, L., Michael W.H., Langevang, T., and Urassa, G., (2015). Coping with the African business environment.

Schillo, S. R. (2011). Entrepreneurial Orientation and Company Performance: Can The Academic Literature Guide Managers? Technology Innovation Review. 1(2): 20-25.

Schumpeter, J. A., [1934] (2008). The Theory of Economic Development: An Inquiry into Profits, Capital, Credit, Interest and the Business Cycle, translated from the German by Redvers Opie, New Brunswick (U.S.A) and London (U.K.): Transaction Publishers. 7-20.

Silinevica, I, (2011). Implementation Problem of Development Strategies: Economic science for rural development conference proceeding. 31(6): 140-145.

Tifre, J. (2014). Entrepreneurial orientation as the growth predictor of small enterprises. Journal of Strategic Marketing. 21(2): 144-167.

URT (2003). Small and medium enterprise development policy. Ministry of industry and trade Dar es salaam, Tanzania.

URT (2012). Micro Small and Medium Enterprises in Tanzania. National Baseline Survey Report.

Wiklund, J., and Shepherd, D. (2009). Entrepreneurial Orientation and Small Business Performance: A Configurationally Approach. Journal of Business Venturing. 20(1): 71-91.

Yahya, A. H., and Mutabarukwa, K. (2015). The Influence of the Factors of Managerial. Competencies among SMEs in Selangor, Malaysia A Preliminary Study of Human Resources. 